\title{
PENGARUH PENGAWASAN PIMPINAN TERHADAP PRODUKTIVITAS KERJA PEGAWAI DI UPT PENGEMBANGAN TANAMAN OBAT, NANGGUNG KABUPATEN BOGOR
}

\author{
${ }^{1)}$ Angga Pratama Santosa, ${ }^{2)}$ Aminudin \\ ${ }^{1)}$ Alumni Program Studi Manajemen, STIE Dewantara \\ J1. Raya Pemda Bojong Depok Baru III, Karadenan, Cibinong, Bogor, Jawa Barat 16913, Indonesia \\ Email: pratamas190396@gmail.com \\ ${ }^{2)}$ Dosen Program Studi Manajemen, STIE Dewantara \\ Jl. Raya Pemda Bojong Depok Baru III, Karadenan, Cibinong, Bogor, Jawa Barat 16913, Indonesia \\ Email: aminudin@dewantara.ac.id
}

\begin{abstract}
This study aims to identify the effect of supervision of the leadership on employee productivity simultaneously at UPT Development of Medicinal Plants Nanggung District Bogor Regency. The research type is explanatory research which analyzed with quantitative approach including Correlation Coefficient (KK), Coefficient of Determination (KD), Simple Linear Regression and Hypothesis Test. The number of samples was 32 respondents with purposive sampling. Data collection techniques through literature study, questionnaire distribution, and observation. Likert scale is used for Questionnaire question. Leadership supervision as independent variable with indicator: work standard setting, measurement of work result, correction action, and feedback. Employee productivity as a dependent variable, with indicators: quantity, quality, timeliness and motivation. Hypothesis test results showed the positive and significant influence of supervision of the leadership to employee work poduktivitas. It means, if the supervision of the leadership increases then it will be followed by increased employee productivity. The result of statistical calculation of Coefficient of Determination $(r 2)$ or $R$ square and Simple Linear Regression equation showed a differentiator between supervisory variables of leadership with productivity variables and any increase in the value of supervisory leadership will increase the influence of work productivity of workers.
\end{abstract}

Keywords: Leadership Supervision, Employee Productivity.

\begin{abstract}
ABSTRAK
Penelitian ini bertujuan untuk mengidentifikasi pengaruh pengawasan pimpinan terhadap produktivitas kerja pegawai secara simultan pada UPT Pengembangan Tanaman Obat Kecamatan Nanggung Kabupaten Bogor. Jenis penelitian tergolong penelitian eksplanatory (explanatory research) yang dianalisis dengan pendekatan kuantitatif meliputi analisis Koefisien Korelasi (KK), Koefisien Determinasi (KD), Regresi Linier Sederhana dan Uji Hipotesis. Jumlah sampel berjumlah 32 orang responden dengan pengambilan secara purposive sampling. Teknik pengumpulan data melalui studi literatur, penyebaran kuisioner, dan observasi. Pertanyaan quisioner menggunakan skala likert. Pengawasan pimpinan sebagai variabel independent dengan indikator: penetapan standar kerja, pengukuran hasil kerja, tindakan koreksi atau perbaikan, dan umpan balik. Produktivitas kerja pegawai sebagai variabel dependent, dengan indikator: kuantitas, kualitas, ketepatan waktu dan motivasi. Hasil uji hipotesis menunjukkan adanya pengaruh positif dan signifikan pengawasan pimpinan terhadap poduktivitas kerja pegawai. Artinya, jika pengawasan pimpinan meningkat maka akan diikuti dengan peningkatan produktivitas kerja pegawai. Hasil penghitungan statistik Koefisien Determinasi $\left(\mathrm{r}^{2}\right)$ atau $\mathrm{R}$ square serta persamaan Regresi Linier Sederhana menunjukan ada pembeda diantara variabel pengawasan pimpinan dengan variabel produktivitas dan setiap ada kenaikan dalam nilai pengawasan pimpinan maka akan menaikan pengaruh produktivitas kerja pekerja.
\end{abstract}

Kata kunci: Pengawasan Pimpinan, Produktivitas Kerja Pegawai. 


\section{PENDAHULUAN}

\subsection{Latar Belakang}

Pembentukan suatu organisasi, baik itu organisasi pemerintah maupun swasta, pada hakekatnya merupakan alat untuk mencapai tujuan. Tercapainya tujuan tersebut, sangat ditentukan oleh seberapa besar kontribusi positif dari para pegawai yang ada didalamnya, serta kemampuan dalam menjalankan tugas pokok dan fungsi dan tanggung jawab sesuai prosedur maupun ketetapan organisasi. Keberhasilan atau kemunduran suatu organisasi, sangat tergantung pada keahlian dan keterampilan pegawai dalam melaksanakan pekerjaannya, sehingga, dapat menghasilkan suatu peningkatan produktivitas kerja pegawai secara nyata.

Produktivitas kerja pegawai, sering diartikan sebagai kemampuan seseorang atau kelompok orang untuk menghasilkan barang atau jasa. Tujuan utama dari peningkatan produktivitas kerja pegawai adalah, agar pegawai mulai dari level bawah hingga level atas mampu menjadi pegawai yang efisien, efektif dan produktif. Seorang pegawai yang efektif, efisien dan produktif adalah pegawai yang memiliki kemampuan dan keterampilan dalam menghasilkan barang atau jasa sesuai mutu yang ditetapkan dalam kurun waktu relatif singkat. Dengan demikian, penting bagi seorang pegawai untuk selalu berusaha meningkatkan produktivitas kerjanya. Hal tersebut, dikarenakan produktivitas kerja pegawai merupakan elemen penentu terhadap perkembangan keberlangsungan organisasi dalam pencapaian hasil kerja yang telah dilakukan sesuai perannya masing-masing, baik secara kualitas, kuantitas maupun tanggung jawabnya untuk pengembangan dan kelancaran segala aktivitas, guna tercapainya tujuan organisasi. Untuk mendapatkan suatu hasil pekerjaan yang baik dan bermutu tinggi, maka diperlukan pengawasan pimpinan yang optimal. Pengawasan merupakan tindakan atau kegiatan pimpinan yang mengusahakan agar pekerjaan terlaksana sesuai dengan rencana yang telah ditetapkan atau hasil kerja yang dikehendaki. Dengan adanya pengawasan pimpinan. Maka, dapat diketahui berbagai kegiatan nyata dari berbagai aspek dan setiap permasalahan pelaksanaan tugastugas dalam lingkungan satuan kerja organisasi. Jika terjadi suatu penyimpangan secara langsung dapat diambil langkah perbaikan dan tindakan untuk mempertahankan kelangsungan hidup dan pertumbuhan organisasi dimasa yang akan datang. Penelitian awal penulis, terhadap produktivitas kerja pegawai pada maka, dapat diketahui berbagai kegiatan nyata dari berbagai aspek dan setiap permasalahan pelaksanaan tugas-tugas dalam lingkungan satuan kerja organisasi. Jika terjadi suatu penyimpangan secara langsung dapat diambil langkah perbaikan dan tindakan untuk mempertahankan kelangsungan hidup dan pertumbuhan organisasi dimasa yang akan datang. Penelitian awal penulis, terhadap produktivitas kerja pegawai. Masih sering terjadinya keterlambatan dalam penyelesaian pekerjaan :

1. Masih terjadinya hambatan dalam pencapaian target kerja;

2. Masih teradapatnya pekerjaan yang tidak sesuai dengan standar kerja;

3. Masih kurang optimalnya pemecahan masalah dalam bekerja;

4. Masih terdapat pegawai yang belum mampu menyelaraskan antara pekerjaan dengan masalah pribadi.

5. Masih terjadinya hambatan dalam pencapaian target kerja;

6. Masih teradapatnya pekerjaan yang tidak sesuai dengan standar kerja;

7. Masih kurang optimalnya pemecahan masalah dalam bekerja;

8. Masih terdapat pegawai yang belum mampu menyelaraskan antara pekerjaan dengan masalah pribadi. 
1.2 Perumusan Masalah

Rumusan masalah pada penelitian adalah sebagai berikut:

1. Apakah ada pengaruh Pengawasan Pimpinan terhadap Produktivitas Kerja Pegawai pada Unit Pelaksana Teknis (UPT) Pengembangan Tanaman Obat Kecamatan Nanggung Dinas Pertanian dan Kehutanan Kabupaten Bogor?

2. Berapa besar pengaruh Pengawasan Pimpinan terhadap Produktivitas Kerja Pegawai pada Unit Pelaksana Teknis (UPT) Pengembangan Tanaman Obat Kecamatan Nanggung Dinas Pertanian dan Kehutanan Kabupaten Bogor

\subsection{Tujuan Penelitian}

Secara umum, tujuan penelitian adalah :

1. Mengkaji dan menguji serta mengetahui sekaligus membuktikan secara ilmiah apakah Pengawasan Pimpinan memiliki pengaruh simultan terhadap variabel Produktivitas Kerja Pegawai pada Unit Pelaksana Teknis (UPT) Pengembangan Tanaman Obat Kecamatan Nanggung Dinas Pertanian dan Kehutanan Kabupaten Bogor.

2. Mengetahui seberapa besar pengaruh dari Pengawasan Pimpinan terhadap variabel Produktivitas Kerja Pegawai pada Unit Pelaksana Teknis (UPT) Pengembangan Tanaman Obat Kecamatan Nanggung Dinas Pertanian dan Kehutanan Kabupaten Bogor.

\subsection{Manfaat Penelitian}

Hasil penelitian ini diharapkan dapat bermanfaat, baik secara akademis maupun praktis, sebagai berikut :

1. Bagi Kampus, dapat digunakan sebagai dasar studi perbandingan dan referensi positif bagi dunia akademis.

2. Bagi penulis, dapat memberikan manfaat dalam perbendaharaan ilmu dan pengalaman serta membuktikan kemampuan penulis untuk menerapkan teori-teori yang telah diperoleh selama masa perkuliahan.

3. Bagi objek yang diteliti, dalam hal ini Unit Pelaksana Teknis (UPT) Pengembangan Tanaman Obat Kecamatan Nanggung Dinas Pertanian dan Kehutanan Kabupaten Bogor. Dapat digunakan sebagai salah satu bahan pertimbangan pengambilan keputusan untuk penetapan strategi yang tepat dalam penerapan pengawasan pimpinan untuk meningkatkan produktivitas kerja pegawai.

4. Bagi pihak lain, hasil penelitian ini dapat dijadikan sebagai bahan informasi dan sebagai bahan referensi tambahan untuk penelitian ilmiah yang akan dilanjutkan selanjutnya.

\section{TINJAUAN PUSTAKA}

\subsection{Landasan Teori}

\subsubsection{Hakekat Pengawasan}

Menurut Handoko (2004), pengawasan adalah suatu usaha sistematik untuk menetapkan standar pelaksanaan kerja dengan tujuan-tujuan perencanaan, merancang sistem informasi umpan balik, membandingkan kegiatan nyata dengan standar yang telah ditetapkan sebelumnya, menentukan dan mengukur penyimpanganpenyimpangan serta mengambil tindakan koreksi yang diperlukan untuk menjamin bahwa semua sumber daya perusahaan dipergunakan dengan cara paling efektif dan efisien dalam pencapaian tujuan-tujuan perusahaan. Sedangkan tujuan pengawasan menurut Kadarman dan Udaya (2001) adalah menemukan kelemahan dan kesalahan untuk kemudian dikoreksi dan mencegah pengulangannya. Disimpulkan bahwa pengawasan adalah rangkaian kegiatan yang dilakukan seorang pimpinan untuk mengukur tingkat efektif dan efisiensi kerja personil dengan menggunakan metode dan alat tertentu dalam usaha mencapai tujuan yang telah ditetapkan sebelumnya. 


\subsubsection{Hakikat Pimpinan}

Sule dan Saefullah (2005), menyebutkan bahwa kepemimpinan dapat diartikan sebagai proses mempengaruhi dan mengarahkan pegawai dalam melakukan pekerjaan yang telah ditugaskan kepada mereka. Nawawi (2003), menjabarkan beberapa fungsi pemimpin yaitu, fungsi pengambil keputusan, instruktif, konsultatif, dan partisipatif dan delegatif. Berdasarkan pendapat para ahli tersebut maka dapat disimpulkan bahwa, pemimpin adalah orang yang melakukan atau menjalankan kepemimpinan (leadership). Adapun istilah "pimpinan" mencerminkan kedudukan (status) seseorang atau sekelompok orang pada hirarki tertentu dalam suatu organisasi formal maupun non formal.

\subsubsection{Pengawasan Pimpinan}

Berdasarkan pendapat para ahli tentang pengawasan dan pimpinan, maka menurut penulis, pengawasan pimpinan adalah proses pengamatan pimpinan, mulai dari penetapan standar kerja, pengukuran hasil kerja, tindakan koreksi/ perbaikan, hingga umpan balik untuk menjamin semua pekerjaan yang sedang berjalan sesuai rencana pada Unit Pelaksana Teknis (UPT) Pengembangan Tanaman Obat Kecamatan Nanggung Dinas Pertanian dan Kehutanan Kabupaten Bogor.

\subsection{Produktivitas Kerja Pegawai}

Produktivitas kerja menurut Hasibuan (2003), adalah perbandingan antara output dengan input dimana output harus mempunyai nilai tambah dan teknik pengerjaannya yang lebih baik. Selanjutnya menurut Simamora (2004), faktor-faktor yang digunakan dalam pengukuran produktivitas kerja meliputi kuantitas kerja; kualitas kerja; dan ketepatan waktu. Produktivitas menurut Umar (2004) mengandung arti sebagai perbandingan antara hasil yang dicapai (output) dengan keseluruhan sumber daya yang digunakan (input). Menurut penulis, produktivitas kerja pegawai dalam penelitian ini adalah Hasil kerja secara kuantitas, kualitas, ketepatan waktu, dan motivasi, yang dilakukan pegawai Unit Pelaksana Teknis (UPT) Pengembangan Tanaman Obat Kecamatan Nanggung Dinas Pertanian dan Kehutanan Kabupaten Bogor.

\subsubsection{Kerja}

Kartono (2010), mengemukakan bahwa kerja merupakan aktivitas dasar dan bagian esensial dari kehidupan manusia, sama halnya aktivitas bermain anak-anak, maka kerja akan memberikan kesenangan dalam arti tersendiri dari kehidupan. Dari uraian diatas, dapat diperoleh suatu pemahaman bahwa kerja adalah suatu rangkaian kegiatan yang dilakukan seseorang dengan tujuan memperoleh hasil tertentu, baik untuk dirinya sendiri maupun lingkungannya.

\subsubsection{Hakekat Pegawai}

Menurut Hasibuan (2003), pegawai atau karyawan adalah seorang pekerja tetap yang bekerja dibawah perintah orang lain dan akan dijamin dan akan mendapat kompensasi serta jaminan. Adapun yang dimaksud dengan pegawai dalam penelitian ini adalah Pegawai Negeri Sipil yang berada pada Unit Pelaksana Teknis (UPT) Pengembangan Tanaman Obat Kecamatan Nanggung Dinas Pertanian dan Kehutanan Kabupaten Bogor.

\subsection{Kajian Penelitian Terdahulu}

Penelitian oleh Sinaga dengan judul "Pengaruh Pengawasan Terhadap Produktivitas Kerja Pegawai Departemen Pekerjaan Umum (Studi pada Direktorat Jenderal Bina Marga SNVT Preservasi dan Pembangunan Jalan dan Jembatan Metropolitan Medan)". Tujuan penelitian untuk mengetahui adakah pengaruh pengawasan terhadap produktivitas kerja pegawai pada Direktorat Jenderal Bina Marga SNVT Preservasi dan Pembangunan 
Jalan dan Jembatan Metropolitan Medan. Hasil penelitian menunjukan terdapat hubungan yang sedang antara pengawasan terhadap produktivitas kerja pegawai serta ada pengaruh yang signifikan antara pengawasan terhadap produktivitas kerja pegawai. Penelitian lainnya, dilakukan Wahyuningrum dengan judul: “ Pengaruh Disiplin Terhadap Produktivitas Kerja Pegawai pada Bagian Administrasi Pemerintahan Sekretariat Daerah Kabupaten Bogor". Tujuan penelitian adalah mengetahui seberapa besar pengaruh pengaruh Disiplin terhadap Produktivitas Kerja Pegawai pada Bagian Administrasi Pemerintahan Sekretariat Daerah Kabupaten Bogor. Hasil penelitian menyimpulkan bahwa terdapat pengaruh disiplin terhadap produktivitas kerja pegawai pada Bagian Administrasi Pemerintahan Sekretariat Daerah Kabupaten Bogor.

\subsection{Kerangka Pemikiran}

Dalam penelitian ini, pengawasan pimpinan merupakan faktor yang mempengaruhi produktivitas kerja pegawai pada Unit Pelaksana Teknis (UPT) Pengembangan Tanaman Obat Kecamatan Nanggung Dinas Pertanian dan Kehutanan Kabupaten Bogor. Dengan demikian, pengawasan pimpinan merupakan variabel bebas (independent variabel), sedangkan produktivitas kerja pegawai adalah variable terikat (dependent variabel). Berdasarkan tinjauan landasan teori dan dari penelitian terdahulu, maka dapat disusun suatu kerangka pemikiran dalam penelitan ini, seperti yang disajikan dalam gambar berikut ini:
Variabel Bebas (X)

Pengawasan Pimpinan

1. Penetapan Standar Kerja,

2. Pengukuran Hasil Kerja,

3. Tindakan Koreksi/Perbaikan,

4. Umpan Balik

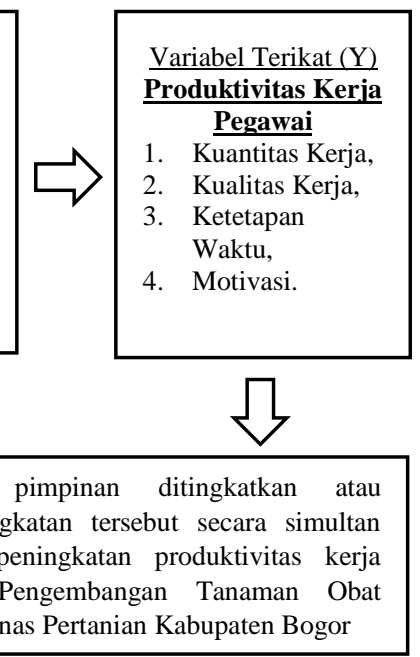

\section{Gambar 1. Kerangka Pemikiran}

\subsection{Hipotesis}

Hipotesis (jawaban sementara) dengan pernyataan (statement) berikut ini:

$\mathrm{H}_{\mathrm{o}}$ : Tidak Terdapat Pengaruh Pengawasan Pimpinan terhadap Produktivitas Kerja Pegawai pada Unit Pelaksana Teknis (UPT) Pengembangan Tanaman Obat Kecamatan Namggung Dinas Pertanian dan Kehutanan Kabupaten Bogor.

$\mathrm{H}_{\mathrm{a}}$ : Terdapat Pengaruh Pengawaswan Pimpinan terhadap Produkjtivitas Kerja Pegawai pada Unit Pelaksana Teknis (UPT) Pengembangan Tanaman Obat Kecamatan Nanggung Dinas Pertanian dan Kehutanan Kabupaten Bogor.

\section{METODE PENELITIAN}

\subsection{Jenis Penelitian}

Berdasarkan tujuannya, jenis penelitian yang digunakan adalah penelitian eksplanatory (explanatory research) dengan pendekatan kuantitatif. Model pengukuran yang tergambar dapat penulis deskripsikan sebagai berikut:

1. $\mathrm{X}$ adalah variabel bebas Pengawasan Pimpinan.

2. $\mathrm{Y}$ adalah variabel terikat Produktivitas Kerja Pegawai. 


\begin{tabular}{llll}
\hline \hline $\begin{array}{l}\text { 3.2 Definisi } \\
\text { Operasional }\end{array}$ & Konseptual & dan & $\begin{array}{l}\text { hanya pada unsur staf atau pelaksana, yakni } \\
\text { sebanyak } 32 \text { responden. }\end{array}$
\end{tabular}

\subsubsection{Pengawasan Pimpinan}

Pengawasan Pimpinan adalah proses pengamatan pimpinan, mulai dari penetapan standar kerja, pengukuran hasil kerja, tindakan koreksi/ perbaikan, hingga umpan balik untuk menjamin semua pekerjaan yang sedang berjalan sesuai rencana pada Unit Pengembangan Teknis (UPT) Pengembangan Tanaman Obat Kecamatan Nanggung Dinas Pertanian dan Kehutanan Kabupaten Bogor.

\subsubsection{Produktivitas Kerja Pegawai}

Hasil kerja secara kuantitas, kualitas, ketepatan waktu, dan motivasi, yang dilakukan pegawai Unit Pengembangan Teknis (UPT) Pengembangan Tanaman Obat Kecamatan Nanggung Dinas Pertanian dan Kehutanan Kabupaten Bogor. Definisi operasional Produktivitas Kerja Pegawai adalah total skor yang diperoleh dari 32 responden, yang diukur menggunakan instrumen Skala Likert yang terdiri dari 20 pertanyaan.

\subsection{Objek, Lokasi dan Waktu Penelitian}

Unit analisisnya yaitu Unit Pelaksana Teknis (UPT) Pengembangan Tanaman Obat Kecamatan Nanggung Dinas Pertanian dan Kehutanan Kabupaten Bogor Kabupaten Bogor dan unit observasinya yaitu seluruh pekerja yang bekerja di UPT tersebut mulai dari Bendahara sampai dengan kepala fungsional penyuluh lapangan. Waktu penelitian dimulai pada Agustus 2016 - Januari 2017.

\subsection{Populasi dan Sampel}

Populasi dalam penelitian ini adalah seluruh pegawai Unit Pelaksana Teknis (UPT) Pengembangan Tanaman Obat Pengembangan Tanaman Obat Kecamatan Nanggung Dinas Pertanian dan Kehutanan Kabupaten Bogor berjumlah 34 orang Pegawai Negeri Sipil. Sampel penelitian

\subsection{Teknik Pengumpulan Data}

Penelitian ini digunakan teknik pengumpulan data melalui studi kepustakaan (data sekunder), observasi dan wawancara.

\subsection{Teknik Analisis Data}

Analisis data menggunakan analisa kuantitatif yang meliputi: Uji Validitas, Uji Reliabilitas, Analisis Koefisien Korelasi, Analisis Koefisien Determinasi, Analisis Regresi Linier Sederhana, Uji Hipotesis.

\section{HASIL DAN PEMBAHASAN}

\subsection{Analisis Deskriptif}

\subsubsection{Pengawasan Pimpinan (X)}

Variabel bebas (X) Pengawasan Pimpinan didasarkan kepada 4 (empat) indikator, yaitu: : Penetapan Standar Kerja, Pengukuran Hasil Kerja, Tindakan koreksi/ Perbaikan dan Umpan Balik.

Dari keseluruhan indikator, yang memiliki skor tertinggi adalah pada Umpan Balik mengenai akuntabilitas kinerja individu terhadap pimpinan sesuai standar yang telah ditetapkan dan dijalankan. Artinya, penilaian positif responden tersebut merupakan cerminan kondisi objektif yang menunjukkan memiliki nilai strategis dan kontribusi yang signifikan dalam meningkatkan Pengawasan Pimpinan.

Sedangkan variabel pengawasan pimpinan yang mempunyai nilai skor terendah adalah pada Tindakan Koreksi/ Perbaikan mengenai adanya solusi yang diberikan pimpinan apabila terjadi kesalahan atau kendala pada saat pelaksanaan kegiatan. Indikator tindakan koreksi/ perbaikan masih cenderung menunjukkan kurang optimal. Oleh karena itu, perlu adanya perhatian dan tindakan khusus kepada pegawai agar lebih patuh terhadap aturan jam kerja sesuai ketetapan standar kerja. Kemudian, koreksi/ 
perbaikan mengenai adanya solusi yang diberikan pimpinan apabila terjadi kesalahan atau kendala pada saat pelaksanaan kegiatan lebih ditingkat lagi.

\subsubsection{Produktivitas Kerja (Y)}

\section{Variabel terikat, pengukuran}

Produktivitas Kerja Pegawai (Y) dilakukan melalui indikator Kuantitas, Kualitas, Ketepatan Waktu dan Motivasi. Berdasarkan hasil perhitungan, skor yang mempunyai nilai skor tertinggi adalah pada Kuantitas. Nilai skor tertinggi tersebut, menunjukkan bahwa responden cenderung memberikan penilaian positif terhadap pernyataan tersebut. Artinya penilaian positif yang diberikan responden tersebut merupakan gambaran kondisi objektif yang menunjukkan bahwa volume pekerjaan individu pegawai yang dihasilkan cukup tinggi, sehingga telah menunjukkan kuantitas kerja pegawai. Sehingga, memiliki nilai strategis dan kontribusi yang signifikan dalam meningkatkan Produktivitas Kerja Pegawai.

Skor terendah terdapat pada Motivasi Kerja pimpinan. Ini menunjukkan bahwa penilaian responden kurang positif. Artinya, kondisi objektif yang direpresentasikan responden mengenai indikator Motivasi masih cenderung menunjukkan kurang optimal sehingga perlu adanya perhatian lebih kepada indikator tersebut, salah satunya yaitu dengan cara pimpinan lebih intensif lagi dalam memberikan motivasi terhadap para pegawai. Hal itu dimaksudkan agar pegawai dapat terdorong dalam melaksanakan pekerjaan sesuai aturan yang berlaku.

\subsection{Analisis Kuantitatif}

Pengolahan data hasil penelitian bisa menggunakan metode analisis data kuantitatif (Arikunto, 2009). Pengolahan statistik dengan rumus Korelasi Pearson Produk Moment dan program SPSS versi 24 for windows untuk menganalisis Pengujian Validitas, Pengujian Reliabilitas, dan Pengujian Koefisien Korelasi (KK), Koefisien Determinasi (KD), Regresi dan Pengujian Hipotesis.

\subsubsection{Uji Validitas Pengawasan Pimpinan \& Produktivitas Kerja}

Tabel 1. Nilai Korelasi (R) Validitas Pengawasan Pimpinan (X)

\begin{tabular}{|c|c|c|c|}
\hline \multirow[t]{2}{*}{ Pernyataan } & \multicolumn{3}{|c|}{ Pengawasan Pimpinan (X) } \\
\hline & $\begin{array}{c}\mathrm{R} \\
\text { hitung }\end{array}$ & $\begin{array}{c}\mathrm{R} \\
\text { tabel }\end{array}$ & Keterangan \\
\hline 1. & 0,590 & 0,349 & Valid \\
\hline 2. & 0,660 & 0,349 & Valid \\
\hline 3. & 0,494 & 0,349 & Valid \\
\hline 4. & 0,605 & 0,349 & Valid \\
\hline 5. & 0,427 & 0,349 & Valid \\
\hline 6. & 0,744 & 0,349 & Valid \\
\hline 7. & 0,474 & 0,349 & Valid \\
\hline 8. & 0,551 & 0,349 & Valid \\
\hline 9. & 0,412 & 0,349 & Valid \\
\hline 10. & 0,632 & 0,349 & Valid \\
\hline 11. & 0,422 & 0,349 & Valid \\
\hline 12. & 0,479 & 0,349 & Valid \\
\hline 13. & 0,573 & 0,349 & Valid \\
\hline 14. & 0,530 & 0,349 & Valid \\
\hline 15. & 0,495 & 0,349 & Valid \\
\hline 16. & 0,376 & 0,349 & Valid \\
\hline 17. & 0,625 & 0,349 & Valid \\
\hline 18. & 0,560 & 0,349 & Valid \\
\hline 19. & 0,399 & 0,349 & Valid \\
\hline 20. & 0,529 & 0,349 & Valid \\
\hline
\end{tabular}

Sumber: Diolah dari hasil penelitian 2016

Dengan $\mathrm{N}=32$ dan tingkat signifikan $5 \%$ maka diperoleh nilai $\mathrm{r}_{\text {tabel }}$ untuk $\mathrm{N}=32$ sebesar 0.349. Nilai $\mathrm{r}_{\text {hitung }}$ dapat dilihat pada tabel uji validitas variabel Pengawasan Pimpinan (X), dimana jika didapat nilai $\mathrm{r}_{\text {hitung }}$ positif dan lebih besar dari $r_{\text {tabel }}$ 
(0.349) maka variabel Pengawasan Pimpinan (X) dapat dinyatakan valid.

Tabel 2. Nilai Korelasi (R) Validitas Produktivitas Kerja Pegawai (Y)

\begin{tabular}{|c|c|c|c|}
\hline \multirow[t]{2}{*}{ Pernyataan } & \multicolumn{3}{|c|}{$\begin{array}{c}\text { Produktivitas Kerja Pegawai } \\
\text { (Y) }\end{array}$} \\
\hline & $\begin{array}{c}\mathrm{R} \\
\text { hitung }\end{array}$ & $\begin{array}{c}\mathrm{R} \\
\text { tabel }\end{array}$ & Keterangan \\
\hline 1. & 0,368 & 0,349 & Valid \\
\hline 2. & 0,479 & 0,349 & Valid \\
\hline 3. & 0,445 & 0,349 & Valid \\
\hline 4. & 0,465 & 0,349 & Valid \\
\hline 5. & 0,436 & 0,349 & Valid \\
\hline 6. & 0,423 & 0,349 & Valid \\
\hline 7. & 0,552 & 0,349 & Valid \\
\hline 8. & 0,464 & 0,349 & Valid \\
\hline 9. & 0,480 & 0,349 & Valid \\
\hline 10. & 0,519 & 0,349 & Valid \\
\hline 11. & 0,562 & 0,349 & Valid \\
\hline 12. & 0,495 & 0,349 & Valid \\
\hline 13. & 0,540 & 0,349 & Valid \\
\hline 14. & 0,380 & 0,349 & Valid \\
\hline 15. & 0,530 & 0,349 & Valid \\
\hline 16. & 0,411 & 0,349 & Valid \\
\hline 17. & 0,454 & 0,349 & Valid \\
\hline 18. & 0,545 & 0,349 & Valid \\
\hline 19. & 0,401 & 0,349 & Valid \\
\hline 20. & 0,447 & 0,349 & Valid \\
\hline
\end{tabular}

Sumber: Diolah dari hasil penelitian 2016

Dengan $\mathrm{N}=32$ dan tingkat signifikan $5 \%$ maka diperoleh nilai $\mathrm{r}_{\text {tabel }}$ untuk $\mathrm{N}=32$ sebesar 0.349. Nilai $r_{\text {hitung }}$ dapat dilihat pada tabel uji validitas variabel Produktivitas Kerja Pegawai (Y), dimana jika didapat nilai $r_{\text {hitung }}$ positif dan lebih besar dari $r_{\text {tabel }}$ (0.349) maka variabel Produktivitas Kerja Pegawai (Y) dapat dinyatakan valid.

\subsubsection{Uji Reliabilitas Pengawasan Pimpinan (X) dan Produktivitas Kerja}

Hasil Uji Reliabilitas variabel Pengawasan Pimpinan (X) dari 20 butir item pernyataan, yaitu nilai Alpa sebesar
0.863 , lebih besar bila dibandingkan dengan tabel harga kritik nilai $\mathrm{r}$ product moment nilai $r_{\text {tabel }}$ sebesar 0.349. Disimpulkan bahwa $r_{\text {alpha }}$ positif dan lebih besar dari harga signifikan, atau $0.863>0.349$, maka instrumen penelitian mengenai variabel Pengawasan Pimpinan (X) adalah Reliabel.

Hasil Uji Reliabilitas variabel Produktivitas Kerja Pegawai (Y) dari 20 butir item pernyataan, yaitu nilai Alpa sebesar 0.813, lebih besar bila dibandingkan dengan tabel harga kritik nilai $\mathrm{r}$ product moment atau nilai $\mathrm{r}_{\text {tabel }}$ sebesar 0.349. Disimpulkan bahwa $r_{\text {alpha }}$ positif dan lebih besar dari harga signifikan, atau $0.813>0.349$. maka dengan demikian instrumen penelitian mengenai variabel Produktivitas Kerja Pegawai (Y) adalah Reliabel.

\subsubsection{Analisis Koefisien Korelasi}

Berdasarkan pengolahan statistik menggunakan rumus Pearson Produk Moment antara Pengawasan Pimpinan dengan Produktivitas Kerja Pegawai diperoleh hasil $r_{x y}=0,9089$ (dibulatkan menjadi 0,909). Selanjutnya berdasarkan pengolahan statistik menggunakan program SPSS versi 24 for windows diperoleh hasil pengukuran Koefisien Korelasi (KK) menunjukkan bahwa hubungan yang terjalin di antara variabel bebas (X) Pengawasan Pimpinan dengan variabel terikat (Y) Produktivitas Kerja Pegawai pada UPT Pengembangan Tanaman Obat Kecamatan Nanggung Dinas Pertanian dan Kehutanan Kabupaten Bogor mencapai 0.909. Bila nilai $r$ dibandingkan dengan Tabel Interpretasi Koefisien Korelasi Nilai r, maka nilai sebesar 0.909 ini masuk ke dalam interval korelasi 0,80 sampai dengan 1,00 yang masuk ke dalam kategori tingkat hubungan sangat kuat. Koefisien Korelasi ini terbilang positif dan sangat signifikan. Artinya, di antara variabel bebas (X) Pengawasan Pimpinan dengan variabel terikat (Y) Produktivitas Kerja Pegawai 
pada Unit Pelaksana Teknis (UPT) Pengembangan Tanaman Obat Kecamatan Nanggung Dinas Pertanian dan Kehutanan Kabupaten Bogor terjalin suatu mekanisme hubungan kausalitas.

\subsubsection{Analisis Koefisien Determinasi}

Besarnya pengaruh variabel Pengawasan Pimpinan (X) terhadap Produktivitas Kerja Pegawai pada Unit Pelaksana Teknis (UPT) Pengembangan Tanaman Obat Kecamatan Nanggung Dinas Pertanian dan Kehutanan Kabupaten Bogor, dengan menggunakan rumus Koefisien Determinasi sebagai berikut:

$\mathrm{KD}=\mathrm{r}^{2} \times 100 \%$

$\mathrm{KD}=(0,909)^{2} \times 100 \%$

$\mathrm{KD}=82,6 \%$

Hasil penghitungan statistik $R$ square diketahui bahwa Koefisien Determinasi (KD) di antara variabel bebas (X) Pengawasan Pimpinan dengan variabel terikat (Y) Produktivitas Kerja Pegawai mencapai 82.6. Artinya, kontribusi pengaruh Pengawasan Pimpinan terhadap peningkatan Produktivitas Kerja Pegawai mencapai $82.6 \%$. Sedangkan sisanya sebesar $17.4 \%$ merupakan kontribusi faktor-faktor lain yang juga turut berpengaruh terhadap variabel Produktivitas Kerja Pegawai pada Unit Pelaksana Teknis (UPT) Pengembangan Tanaman Obat Kecamatan Nanggung Dinas Pertanian dan Kehutnan Kabupaten Bogor, namun tidak diteliti.

\subsubsection{Analisis Regresi}

Selanjutnya untuk meramalkan Y jika $X$ berubah-rubah dihitung menggunakan persamaan regresi linier sederhana dengan rumus:

$$
\hat{\mathrm{Y}}=\mathrm{a}+b \mathrm{X}
$$

Berdasarkan pengolahan statistik diperoleh hasil variabel Produktivitas Kerja Pegawai terhadap Pengawasan Pimpinan berdasarkan perhitungan di atas, menghasilkan arah regresi atau koefisien regresi (b) sebesar 0,804 dan konstanta (a) sebesar 11,473. Dengan demikian, bentuk hubungan antara kedua variabel tersebut dapat digambarkan oleh persamaan regresi yaitu : $\hat{Y}=11,473+0,804 X$. Garis regresi linier ini mengandung arti bahwa apabila nilai $X$ naik satu satuan akan diikuti dengan kenaikan $Y$ sebesar satu satuan pada konstanta $\mathrm{a}=11,473$. Interpretasi persamaan

regresi $\hat{Y}=11,473+0,804 \mathrm{X}$ adalah jika pengawasan pimpinan dengan produktivitas kerja pegawai diukur dengan instrumen yang dikembangkan dalam penelitian ini, maka setiap peningkatan skor pengawasan pimpinan sebesar satu satuan, maka dapat diestimasikan skor pada produktivitas kerja pegawai akan meningkat sebesar 0,804 x 1 satuan pada arah yang sama pada konstanta 11,473 .

\subsubsection{Uji Hipotesis}

Pengujian Hipotesis digunakan rumus statistik $t_{\text {hitung. }}$. Hasil penghitungan statistik

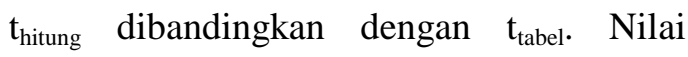
pembanding ditentukan berdasarkan jumlah sampel penelitian 32 responden dan taraf kepercayaan yang dipilih $\alpha=0,05$. Rumus statistik Uji $t$ yang digunakan adalah sebagai berikut: Nilai $t_{\text {hitung }}$ yang diperoleh dalam analisa data pengaruh Pengawasan Pimpinan terhadap Produktivitas Kerja Pegawai adalah sebesar 11,939. Sedangkan $t_{\text {tabel }}$ dengan tingkat signifikansi $(\alpha=0,05)$ dan df (derajat kebebasan) $=\mathrm{n}-2=32-2=$ 30 adalah sebesar 2,042. Karena $t_{\text {hitung }}>$ $\mathrm{t}_{\text {tabel }}(11,939>2,042)$, maka $\mathrm{H}_{0}$ ditolak dan $\mathrm{H}_{\mathrm{a}}$ diterima. Artinya, ada pengaruh yang positif dan signifikan Pengawasan Pimpinan terhadap Produktivitas Kerja Pegawai. Terbukti, ada pengaruh yang positif dan signifikan Pengawasan Pimpinan terhadap Produktivitas Kerja Pegawai. Dengan demikian, hipotesis sudah teruji bahwa terdapat pengaruh yang positif Pengawasan Pimpinan terhadap Produktivitas Kerja Pegawai pada Unit 
Pelaksana Teknis (UPT) Pengembangan

Tanaman Obat Kecamatan Nanggung Dinas

Pertanian dan Kehutanan Kabupaten Bogor.

Hasil pengujian hipotesis dapat dikemukakan dengan gambar kurva penolakan/penerimaan sebagai berikut:

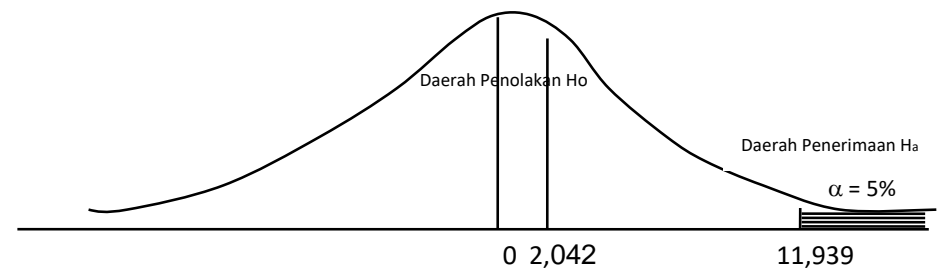

Gambar 1. Kurva Pengujian

Signifikansi Hipotesis dengan Uji Satu Pihak (One Tailed).

Berdasarkan perhitungan dan ditunjukkan pada gambar 1. diatas, maka dinyatakan bahwa t hitung sebesar 11,939 jatuh pada daerah penolakan $\mathrm{H}_{0}$, maka dapat dinyatakan hipotesis nol yang menyatakan Pengawasan Pimpinan tidak berpengaruh positif terhadap Produktivitas Kerja Pegawai ditolak dan hipotesis alternatif yang menyatakan Pengawasan Pimpinan berpengaruh positif terhadap Produktivitas Kerja Pegawai diterima. Dengan demikian, maka dapat disimpulkan bahwa koefisien korelasi Pengawasan Pimpinan berpengaruh positif dan signifikan terhadap Produktivitas Kerja Pegawai sebesar 82,6 adalah signifikan.

\subsection{Analisa Data Hasil Penelitian}

Berdasarkan hasil pengujian hipotesis dapat dinyatakan pula di antara pengawasan pimpinan yang diposisikan sebagai variabel bebas dengan produktivitas kerja pegawai yang diposisikan sebagai variabel terikat terjadi suatu mekanisme hubungan sebab dan akibat. Mekanisme hubungan sebab dan akibat dapat diartikan sebagai suatu proses hubungan situasional, hubungan kondisional atau hubungan fungsional di antara indikator-indikator pengawasan pimpinan dengan indikator produktivitas kerja pegawai.

Hasil persamaan regresi linier sederhana menunjukan pengawasan pimpinan memiliki pengaruh positif yang kuat terhadap produktivitas kerja pegawai pada Unit Pelaksana Teknis (UPT) Pengembangan Tanaman Obat Kecamatan Nanggung Dinas Pertanian dan Kehutanan Kabupaten Bogor. Hasil penghitungan statistik tersebut, juga menunjukkan bahwa apabila pengawasan pimpinan ditingkatkan atau meningkat, maka peningkatan tersebut secara simultan akan mengakibatkan peningkatan produktivitas kerja pegawainya. Peningkatan yang demikian itu, dapat terjadi karena di antara pengawasan pimpinan dengan produktivitas kerja pegawai terjalin suatu mekanisme hubungan sebab dan akibat. Artinya, tinggi atau rendahnya Produktivitas Kerja Pegawai pada Unit Pelaksana Teknis (UPT) Pengembangan Tanaman Obat Kecamatan Nanggung Dinas Pertanian dan Kehutanan Kabupaten Bogor sangat tergantung pula pada Pengawasan Pimpinan dalam melaksanakan aktivitas pekerjaan.

Meningkatkan Pengawasan Pimpinan dengan cara meningkatkan empat indikator kajian, yaitu: Penetapan Standar Kerja, Pengukuran Hasil Kerja, Tindakan koreksi/ Perbaikan dan Umpan Balik. Sedangkan untuk meningkatkan Produktivitas Kerja Pegawai melalui peningkatan indikator Kuantitas, Kualitas, Ketepatan Waktu dan Motivasi. Dalam konteks itu, Pengawasan Pimpinan adalah bagian terdalam kepribadian yang dimiliki seorang pimpinan dalam mengambil langkah perbaikan dan tindakan untuk mempertahankan kelangsungan hidup dan pertumbuhan organisasi dimasa yang akan datang. Selain itu, pengawasan pimpinan juga menjadi faktor penting yang bernilai strategis bagi terwujudnya keterpaduan dan kelancaran produktivitas kerja pegawai.

Dengan demikian, pemahaman pengawasan pimpinan sebagai suatu proses 


pengamatan pimpinan, mulai dari
penetapan standar kerja, pengukuran hasil kerja, tindakan koreksi/ perbaikan, hingga umpan balik untuk menjamin semua pekerjaan yang sedang berjalan sesuai rencana dan memiliki pengaruh terhadap produktivitas kerja sangat penting untuk menilai peran strategis para pegawainya.

Secara kondisional Pengawasan Pimpinan sangat berpengaruh terhadap Produktivitas Kerja Pegawai pada UPT Pengembangan Tanaman Obat Kecamatan Nanggung Dinas Pertanian dan Kehutanan Kabupaten Bogor. Pengaruh Pengawasan Pimpinan tersebut, sebesar 82,6\%.

Selain itu, peneliti juga dapat mengetahui variabel lain yang ikut berpengaruh terhadap Produktivitas Kerja Pegawai pada UPT Pengembangan Tanaman Obat Kecamatan Nanggung Dinas Pertanian dan Kehutanan Kabupaten Bogor tetapi tidak diukur atau diteliti dalam penelitian ini, yaitu sebesar $17,4 \%$, seperti Masih sering terjadinya keterlambatan dalam penyelesaian pekerjaan, kemudian masih terjadinya hambatan dalam pencapaian target kerja, selanjutnya masih terdapatnya pekerjaan yang tidak sesuai dengan standar kerja, dan masih kurang optimalnya pemecahan masalah dalam bekerja, serta masih terdapat pegawai yang belum mampu menyelaraskan antara pekerjaan dengan masalah pribadi.

\section{KESIMPULAN DAN SARAN}

\subsection{Kesimpulan}

Kesimpulan penelitian, dapat dijelaskan sebagai berikut:

1. Hasil pengujian Hipotesis menunjukkan terdapat pengaruh positif dan signifikan Pengawasan Pimpinan terhadap Produktivitas Kerja Pegawai pada pada Unit Pengembangan Teknis (UPT) Pengembangan Tanaman Obat Kecamatan Nanggung Dinas Pertanian dan Kehutanan Kabupaten Bogor.

2. Hasil pengukuran koefisien korelasi terbilang positif dan sangat signifikan.
Artinya bahwa apabila kompetensi ditingkatkan atau meningkat maka peningkatan tersebut secara stimulan diikuti dengan peningkatan Produktivitas Kerja Pegawai pada Unit Pengembangan Teknis (UPT) Pengembangan Tanaman Obat Kecamatan Nanggung Dinas Pertanian dan Kehutanan Kabupaten Bogor.

3. Hasil Pengukuran Koefisien Determinasi $\left(\mathrm{r}^{2}\right)$ atau $R$ square menjelaskan dari variabel Pengawasan Pimpinan, dan atau besarnya pengaruh variabel Pengawasan Pimpinan terhadap variabel Produktivitas Kerja Pegawai adalah 82,6\%. Sisanya sebesar $17,4 \%$ merupakan pengaruh variabel-variabel lain terhadap variabel Produktivitas Kerja Pegawai, namun tidak diteliti

4. Hasil pengukuran persamaan regresi sederhana dengan rumus $\hat{\mathrm{Y}}=\mathrm{a}+b \mathrm{X}$ atau $(\hat{\mathrm{Y}}=11,473+0,804 \mathrm{X})$ menunjukkan bahwa apabila Pengawasan Pimpinan ditingkatkan maka akan diimbangi dengan peningkatan Produktivitas Kerja Pegawai.

\subsection{Saran}

Saran yang dapat disampaikan setelah penelitian ini adalah :

1. Perlu adanya perhatian ekstra dari pimpinan berupa pengawasan kepada pegawai khususnya terhadap kepatuhan jam kerja sesuai ketetapan kerja. Hal itu, merujuk kepada kondisi objektif yang direpresentasikan responden mengenai indikator pengukuran hasil kerja, masih cenderung kurang optimal, serta tindakan koreksi/ perbaikan yang masih lambat.

2. Pimpinan lebih intensif lagi dalam memberikan motivasi terhadap para pegawai. Sehingga, pegawai dapat terdorong untuk melaksanakan kerja 
sesuai aturan yang berlaku. Hal itu, merujuk kepada kondisi objektif yang direpresentasikan responden mengenai indikator motivasi masih cenderung menunjukkan kurang optimal.

\section{DAFTAR PUSTAKA}

Anoraga, Pandji. 2000. Manajemen Bisnis.

: Rineka Cipta. Jakarta.

Arikunto, 2009 Manajemen Penelitian. : Rineka Cipta. Bandung.

Hasibuan, Malayu S.P. 2003. Manajemen Sumber Daya Manusia. Edisi Revisi: Bumi Aksara. Jakarta.

Handoko, T. Hani. 2004 Organisasi Perusahaan, Teori, Struktur dan Perilaku : BPFE. Yogyakarta.

Kadarman, A.M dan Udaya, Jusuf. 2001. Pengantar Ilmu Manajemen: PT. Prenhallindo, Jakarta.

Kartono, Kartini. 2010. Pemimpin dan Kepemimpinan : Raja Grafindo Persada. Jakarta.

Mohyi, Ach. 2006. Teori dan perilaku Organisasi : UMM Press, Malang.

Nawawi, Hadari. 2003. Kepemimpinan Mengefektifkan Organisasi: Gajah Mada University Press. : Yogyakarta.

Sarwoto. 2001. Dasar-dasar Organisasi dan Manajemen: Ghalia Indonesia Jakarta.

Sastrohadiwiryo, B. Siswanto. 2002. Manajemen Tenaga Kerja Indonesia.: Bumi Aksara. Jakarta.

Simamora, Henry. 2004. Manajemen Sumber Daya Manusia : STIE YKPN. Yogyakarta.

Sule, Erni Tisnawati dan Saefullah.2005. Pengantar Manajemen: Kencana, Jakarta.

Umar, Husein. 2004. Riset Sumber Daya Manusia dalam Organisasi, : PT. Gramedia Pustaka Utama, Jakarta. 